\title{
EVALUATION OF DOWNY MILDEW (HYALOPERONOSPORA BRASSICAE) INFECTION SEVERITY ON DIFFERENT CRUCIFEROUS OILSEED CROPS
}

\author{
Eve RUNNO-PAURSON, Institute of Agricultural and Environmental Sciences, Estonian University of Life Sciences, Kreutzwaldi \\ 1a, EE51006 Tartu, Estonia, eve.runno-paurson@emu.ee (corresponding author) \\ Peeter LÄÄNISTE, Institute of Agricultural and Environmental Sciences, Estonian University of Life Sciences, Kreutzwaldi 1a, \\ EE51006 Tartu, Estonia, peeter.laaniste@emu.ee \\ Viacheslav EREMEEV, Institute of Agricultural and Environmental Sciences, Estonian University of Life Sciences, Kreutzwaldi 1a, \\ EE51006 Tartu, Estonia \\ Eve KAURILIND, Institute of Agricultural and Environmental Sciences, Estonian University of Life Sciences, Kreutzwaldi 1a, \\ EE51006 Tartu, Estonia, eve.kaurilind@emu.ee \\ Hanna HÕRAK, Institute of Agricultural and Environmental Sciences, Estonian University of Life Sciences, Kreutzwaldi 1a, \\ EE51006 Tartu, Estonia, hanna.horak@emu.ee \\ Ülo NIINEMETS, Institute of Agricultural and Environmental Sciences, Estonian University of Life Sciences, Kreutzwaldi 1a, \\ EE51006 Tartu, Estonia / Estonian Academy of Sciences, Kohtu 6, EE10130 Tallinn, Estonia ylo.niinemets@emu.ee \\ Luule METSPALU, Chair of Plant Health, Institute of Agricultural and Environmental Sciences, Estonian University of Life Sciences, \\ Kreutzwaldi 1a, EE51006 Tartu, Estonia, luule.metspalu@emu.ee
}

\begin{abstract}
Diseases constitute an important economic problem in oilseed rape (Brassica napus) cultivation. Although downy mildew has been counted so far as a minor disease, under intensive cultivation system and short rotation interval, the impact of diseases could increase in the future, especially under predicted more humid northern climatic conditions. This research study is the first report about the severity of downy mildew infection on cruciferous crops in Estonia. During two years (2010 - 2011), downy mildew infection severity was assessed in six different cruciferous crops (B. napus, B. juncea, B. nigra, Sinapis alba, Raphanus sativus, Eruca sativa) in field trials located in Eerika, Tartu County, Estonia. On both study years, four disease assessments were done. Downy mildew infection started a week earlier in 2010, but the overall disease pressure was lower compared to 2011. Based on our field trial results, $S$. alba, E. sativa and $R$. sativus plants were significantly more resistant to downy mildew compared to other tested crops. Furthermore, in 2010 downy mildew symptoms were not recorded on two cruciferous species $E$. sativa and $R$. sativus. Brassica nigra and B. napus plants were the most susceptible to downy mildew, with especially severe infection in 2011. Based on our two years data, downy mildew can damage foliage on spring oilseed rape (B. napus) and black mustard (B. nigra) in a notable extent. We conclude that downy mildew is an important pathogen, which should be monitored on different oilseed cruciferous crops in Estonia.
\end{abstract}

Keywords: Brassica napus, B. juncea, B. nigra, Sinapis alba, Raphanus sativus, Eruca sativa, downy mildew

\section{INTRODUCTION}

Cruciferous oil seed crops such as oilseed rape (Brassica napus L.) and turnip rape (Brassica rapa L.) have been important cash crops for farmers in Estonia since the end of 1990s. Since then, the cultivation area has increased tremendously and culminated in 2010 at 100000 ha that comprised approximately $26 \%$ of total cultivation area of cerealdominated crop rotations (Järvan, 2016; Statistics Estonia, 2019). However, the cultivation area has now stabilized at 75 000 ha (16\%) (Statistics Estonia, 2019). Growth in extensive monocultures and short rotation has caused serious problems for oilseed rape and turnip rape with several insects like pollen beetle (Brassicogethes aeneus Fabr.) (Metspalu et al., 2015), flea beetles (Phyllotreta spp.) (Metspalu et al., 2014), etc. and several soilborne diseases such as Sclerotinia stem rot (Sclerotinia sclerotiorum (Lib.) de Bary) (Ilumäe et al., 2009) and clubroot (Plasmodiophora brassicae Woronin) (Järvan, 2016), which are difficult to control. Heavy input of synthetic pesticides for disease and insect control puts considerable economic pressure on farmers (Ilumäe, 2013) and causes resistance to widespread pesticides (Brandes \& Heimbach, 2018; Kovacs et al., 2015).

The cruciferous pathogen $H$. brassicae is an obligate oomycete. Although the downy mildew (Hyaloperonospora brassicae (Gaum) has been considered a minor disease of oilseed rape in Australia (Van de Wouw et al., 2016), in the Baltic region (Latvia and Lithuania), UK (Hardwick et al., 1991) and elsewhere (Bankina et al., 2012; Petraitiene, 2006), still lately has reported by Mohammed et al. (2017) severe epidemics in Western Australia. The pathogen H. brassicae is widespread and harmful for cruciferous oilseed crops and vegetables (Mohammed et al., 2018a; Coelho \& Monteiro,

Copyright ( $\odot 2019$ The Authors. Published by Vytautas Magnus University. This is an open-access article distributed under the terms of the Creative Commons Attribution License (CC BY 4.0), which permits unrestricted use, distribution, and reproduction in any medium, provided the original author and source are credited. 
2018; Coelho \& Montiro, 2003). Symptoms appear as white fungal growth that develops on the underside of leaves and yellow/brown irregular lesions that develop on the upper leaf side. Although downy mildew can infect the host plant during growing period, it is still most severe on oilseed rape at the seedling stage when the pathogen can cause seedling death (Oxley \& Evans, 2009). Damage is worse in wet conditions at approximately $15^{\circ} \mathrm{C}$ (Saharam et al., 2018) and in case of infection on pods (Hardwick et al., 1991). Furthermore, under favourable conditions and in intensive cultivation with short crop rotation, downy mildew could become an acute problem in cruciferous oilseed crops in the northern Baltic region.

Different cruciferous crops like winter oilseed rape, white mustard (Sinapis alba L.) and oilseed radish (Raphanus sativus (L.)) have been used quite successfully as green manure and cover crops to supress soilborne pathogens and reduce foliar disease progression (Larkin et al., 2010; Larkin \& Halloran, 2014; Larkin, 2017; Olanya et al., 2014; Runno-Paurson et al., 2014, 2015, 2019). Use of cover crops could be a promising alternative disease control strategy for environmentally friendly producers. Oilseed radish, rucola (Eruca sativa (Mill)), white mustard and mustard green (brown mustard) (Brassica juncea L.) have been previously reported as effective trap plants for flea beetles, pollen beetles and cabbage seedpod weevil (Ceutorhynchus obstrictus (Marsham) (Veromann et al., 2012; Metspalu et al., 2014; Kovacs et al. 2017). However, the pathogen $H$. brassicae persists as oospores on infected plant debris in the soil (George, 2014). Thus, it is very important that cover crop plants are not susceptible to downy mildew and pathogen does not accumulate in the soil.

Behind the high diversity of Baltic potato late blight pathogen (Phytophthora infestans) populations is the result of sexual reproduction, which benefits the survival, adaptability and diversity of the pathogen in the climate of North-Eastern Europe (Kiiker et al., 2018, 2019). Furthermore the presence of sexual reproduction changes the epidemiology (Mayton et $a l ., 2000)$ and increases the adaptability of the pathogen, thus changes the way in which disease control must be approached (Yuen \& Andersson 2013). There are reports from higher pathotypic variation on B. oleracea (Coelho et al., 2012). Thus under the changed climate conditions (Sepp et al., 2018), in case of P. infestans, oomycete H. brassicae could happen similarly scenario that through sexual reproduction the genetic diversity and control problems increases in northern Europe.

By now, the knowledge about downy mildew infection severity on oilseed rape, including other cruciferous oilseed crops, has been missing in the northern Baltic region. Therefore, the main aim of this study was to evaluate downy mildew development and severity on spring oilseed rape, and on five alternative cruciferous oil seed crops (B. juncea, B. nigra, S. alba, R. sativus, Eruca sativa) with the purpose to find species that are less susceptible to disease for possible application as cover crop, in trap cropping or seed production. The study was conducted in climatically two different years allowing for characterization of the variability of downy mildew infection severity.

\section{MATERIALS AND METHODS}

\section{Field experiment}

Downy mildew (H. brassicae) occurrence was evaluated in 2010 and 2011 in six different cruciferous plant species in the Eerika experimental field of the Estonian University of Life Sciences in 2010 and 2011, Tartu County, Estonia $\left(58^{\circ} 21^{\prime} \mathrm{N}, 26^{\circ} 39^{\prime} \mathrm{E}\right)$. The plants were grown in a randomized complete block design with three replicates of each of the following species: spring oilseed rape (Brassica napus (L.) cv. 'Maskot'), mustard green (brown mustard) (B. juncea (L.) Czern.) cv. 'Jadrjonaja', black mustard (B. nigra (L.) W. D. J. Koch), rucola/arugula (Eruca sativa subsp. sativa ((Mill.) Thell.) (=E. sativa) cv. 'Poker'), oilseed radish (Raphanus sativus (L.) var. oleiformis (Pers.) =R. sativus), cv. 'Bille') and white mustard (Sinapis alba (L.), cv. 'Branco'). In both years, seeds were obtained from the seed collection of the Estonian University of Life Sciences. In both study years, the size of each plot was $1 \mathrm{~m} \times 5 \mathrm{~m}$ as recommended in other studies for cruciferous crops (Veromann et al., 2012, Kalischuk \& Dosdall 2004, Kovacs et al., 2017). To minimize inter-plot interactions, there was an $1 \mathrm{~m}$ wide buffer zone of bare soil around each plot. The whole experimental field was surrounded by a hay meadow. Plots were sown on the $12^{\text {th }}$ of May in 2010 and $9^{\text {th }}$ of May in 2011, at 250 seeds per $\mathrm{m}^{2}$ (seeds obtained from the seed collection of the Estonian University of Life Sciences). The germination of seed was similar for different species in different years, and no differences were noticed in plant density (on average 200 plants per plot) between plots. In both years, the same standard crop management practices were used in all trial plots. The fertilizers and pesticides were not used. The plant growth stage (BBCH) was assessed using the decimal code system of Lancashire et al. (1991).

\section{Weather conditions}

In 2010, the air temperature (Eerika Weather Station present at the site) in May and June were similar to the longterm (42-year) average, but in July, the temperature was $4.1^{\circ} \mathrm{C}$ higher than the long-term average (Table 1). The rainfall in 2010 was similar to the long-term average in June, but in July, it was lower with only $38.4 \mathrm{~mm}$ (70.6 mm for 42 -year average). In 2011, the temperature in May was similar to the long-term average, but June was hotter by $1.9^{\circ} \mathrm{C}$ and July hotter by $2.4^{\circ} \mathrm{C}$ (Table 1). The rainfall in 2011 May was similar to the long-term average, but much lower in June and July (Table 1). In the third ten-day period of July, the warm conditions (with temperatures over $30^{\circ} \mathrm{C}$ for more than 10 days) were suppressive/unfavourable to downy mildew infection.

\section{Downy mildew assessment}

Downy mildew occurrence was monitored from June 23 to July 122010 (four observations) and from $1^{\text {st }}$ of July to $22^{\text {nd }}$ of July 2011 (four observations), at GS $31-35$ to GS 75 - 77 (Table 2). Disease assessments were made under natural infection conditions as a percentage of total foliage once each week, until the culmination of the disease. In all species in each of the replications, ten randomly selected plants per plot were assessed for downy mildew infection. Downy mildew infection on test plants was assessed according to the $0-100 \%$ scale (EPPO Bulletin, 2003). The area under the disease progress curve (AUDPC) was calculated from the date of first occurrence of downy mildew until the 
last observation of the disease in the trial according to Shaner \& Finney (1977) by using the following formula: $\Sigma R=$ $\left.n\left[\left(R_{\mathrm{i}+1}+R_{\mathrm{i}}\right) / 2\right)\right]\left(t_{\mathrm{i}+1}-t_{\mathrm{i}}\right)$, where $R_{\mathrm{i}}$ is the disease severity (percentage leaf surface blighted) for the previous $(i$ th observation), and $R_{\mathrm{i}+1}$ the severity for the current observation and $t_{\mathrm{i}}$ and $t_{\mathrm{i}+1}$ are the corresponding times of measurements (day of year), and $n$ is the total number of observations.

Table 1. Average monthly temperatures $\left({ }^{\circ} \mathrm{C}\right)$ and precipitation $(\mathrm{mm})$ in Eerika experimental field during the vegetation and the corresponding long-term averages (1969-2011).

\begin{tabular}{|c|c|c|c|c|c|c|c|}
\hline \multirow{3}{*}{ Month } & \multirow{3}{*}{$\begin{array}{l}\text { Ten-day } \\
\text { period }\end{array}$} & \multirow{2}{*}{\multicolumn{3}{|c|}{$\frac{\text { Average temperature }\left({ }^{\circ} \mathrm{C}\right)}{\text { Year }}$}} & \multicolumn{3}{|c|}{ Sum of rainfall $(\mathrm{mm})$} \\
\hline & & & & & \multicolumn{3}{|c|}{ Year } \\
\hline & & 2010 & 2011 & $1969-2011$ & 2010 & 2011 & $\begin{array}{c}1969-2011 \\
\text { (average) }\end{array}$ \\
\hline \multirow{3}{*}{ May } & I & 7.3 & 8.0 & 9.7 & 39.2 & 0.2 & 12.9 \\
\hline & II & 16.7 & 11.8 & 11.4 & 44.6 & 46.6 & 20.9 \\
\hline & III & 12.4 & 13.0 & 12.8 & 13.6 & 11.6 & 22.8 \\
\hline & I & 13.3 & 19.7 & 14.9 & 41.4 & 0.0 & 20.9 \\
\hline \multirow{3}{*}{ June } & II & 13.6 & 15.9 & 15.1 & 17.8 & 24.8 & 26.9 \\
\hline & III & 15.9 & 16.2 & 16.2 & 38.8 & 10.4 & 28.0 \\
\hline & I & 19.9 & 20.0 & 17.3 & 11.6 & 9.2 & 19.3 \\
\hline \multirow[t]{2}{*}{ July } & II & 22.9 & 18.6 & 17.4 & 3.0 & 30.4 & 24.8 \\
\hline & III & 22.4 & 21.0 & 17,8 & 23.8 & 8.6 & 26.5 \\
\hline May-July & I-III & 16.0 & 16.0 & 14.7 & 233.8 & 141.8 & 203.0 \\
\hline
\end{tabular}

\section{Data analysis}

Statistical analysis of collected data was performed with Statistica 13 (Quest Software Inc, Aliso Viejo, CA, USA). Differences in the severity of downy mildew infection in dependence of year, cruciferous crop species and their interaction were tested by ANOVA. Both factors "year" and "species" were treated as fixed categorical variables. Tukey HSD posthoc tests $(P=0.05)$ were applied to separate the differences among the means between years and cruciferous crop species. The level of statistical significance for all effects was $P=0.05$ except when noted.

Table 2. Growth stages (GS) of studied cruciferous species at each observation date in 2010 and 2011.

\begin{tabular}{|c|c|c|c|c|c|c|}
\hline \multirow{3}{*}{ Species } & \multicolumn{6}{|c|}{ Disease evaluation date } \\
\hline & 2010 & 23 June & 30 June & 7 July & 12 July & - \\
\hline & 2011 & 23 June & 1 July & 8 July & 15 July & 22 July \\
\hline \multirow{3}{*}{ B. napus } & Year & & & & & \\
\hline & 2010 & $55-60$ & $61-63$ & $65-68$ & $68-71$ & \\
\hline & 2011 & $60-62$ & $65-68$ & $68-70$ & $71-72$ & $72-74$ \\
\hline \multirow[t]{2}{*}{ B. nigra } & 2010 & $58-60$ & $65-67$ & $68-70$ & $71-72$ & \\
\hline & 2011 & $63-65$ & $67-69$ & $71-72$ & $72-74$ & $75-77$ \\
\hline \multirow[t]{2}{*}{ B. juncea } & 2010 & $55-60$ & $65-67$ & $69-70$ & $71-72$ & \\
\hline & 2011 & $63-65$ & $68-69$ & $71-72$ & $73-74$ & $75-77$ \\
\hline \multirow[t]{2}{*}{ E. sativa } & 2010 & $31-35$ & $55-57$ & $57-63$ & $63-66$ & \\
\hline & 2011 & $55-62$ & $61-63$ & $65-67$ & $68-69$ & $71-72$ \\
\hline \multirow[t]{2}{*}{ R. sativus } & 2010 & $31-34$ & $57-59$ & $55-63$ & $58-65$ & \\
\hline & 2011 & $55-62$ & $63-65$ & $67-68$ & $71-73$ & $73-75$ \\
\hline \multirow[t]{2}{*}{ S. alba } & 2010 & $62-64$ & $68-70$ & $72-74$ & $72-74$ & \\
\hline & 2011 & $65-67$ & $71-72$ & $73-74$ & $73-74$ & $75-77$ \\
\hline
\end{tabular}

\section{RESULTS AND DISCUSSION}

In 2010, first occurrence of downy mildew infection was found on the 23 June with slight infection on S. nigra and B. napus plants $\left(F_{5,12}=5.85, p<0.01\right)$ (Figure 1a). On the 30 June, the downy mildew infection on $B$. juncea plants reached $11.7 \%$ (average $\pm \mathrm{SE}$ of replicate plots $0.50 \%$ ), which was significantly higher than that on other test plant species $\left(F_{5,12}=13.52, p<0.001\right)$. At that date, the plants of $S$. alba were only slightly infected (Figure 1a). Significantly higher downy mildew infection was recorded a week later on the 7 July; at that date, the infection reached $40.4 \%$ ( \pm SE $11.0 \%)$ on B. nigra and $20.1 \%$ ( \pm SE 2.6\%) on B. juncea (Figure 1a). Hereafter the disease progression diminished and culminated at $48.8 \%$ ( \pm SE $13.0 \%)$ infection on B. nigra plants and $44 \%$ ( \pm SE $7.0 \%)$ infection on B. juncea plants (Figure 1a). Downy mildew infection was not found on E. sativa and $R$. sativus plants during the 2010 growing season (Figure 1a). 

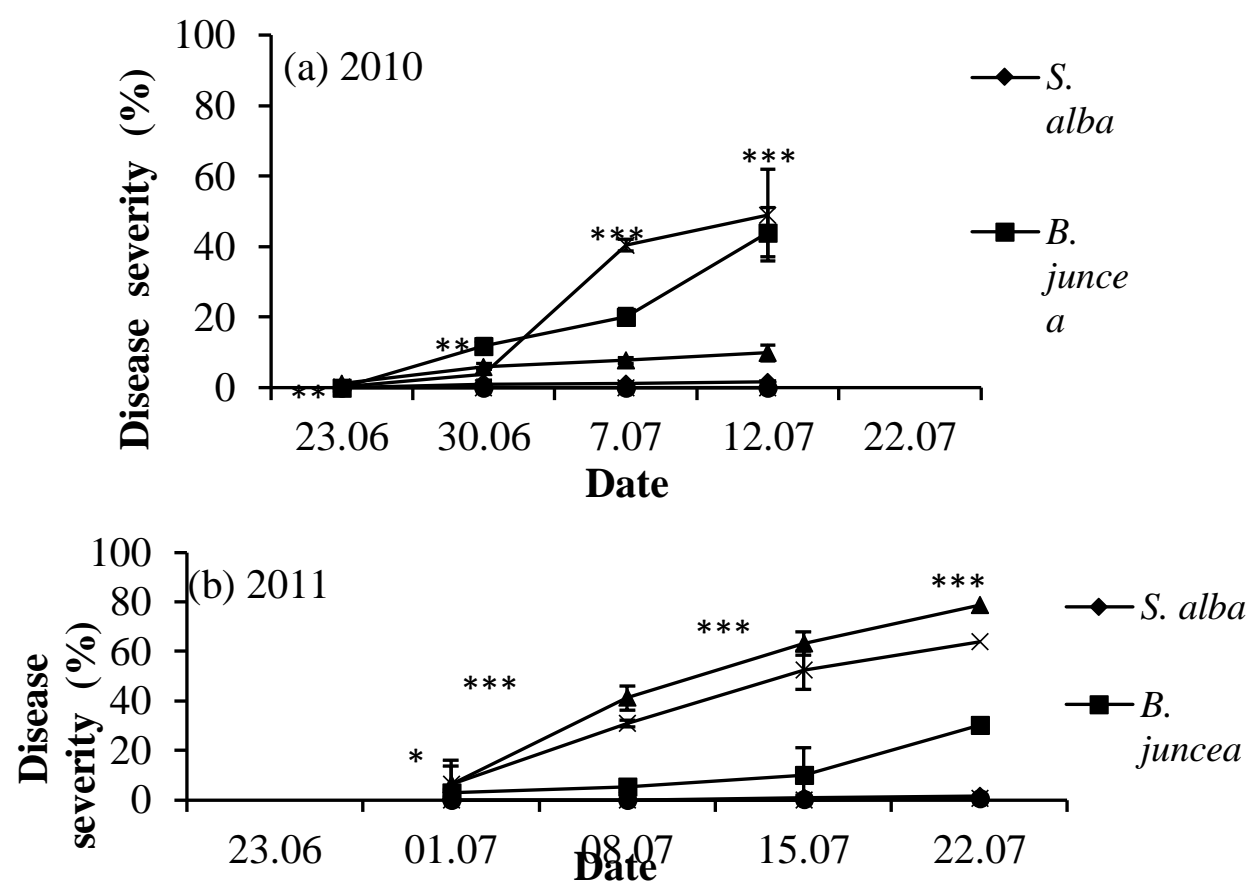

* Error bars are standard error of the means. The asterisks demonstrate the significance of the species effect. Significant at $P<0.05$; ** Significant at $P<0.01 ; * * *$ Significant at $P<0.001$

Figure 1. Development of downy mildew (H. brassicae) on six different cruciferous oilseed crops in 2010 (a) and 2011 (b).

In 2011, first downy mildew symptoms were found on the 1 July on B. napus, B. nigra and B. juncea plants (Figure 1b). First disease symptoms were recorded on $S$. alba two weeks later on the 15 July (Figure 1b) and disease development culminated at very low level with $1.6 \%$ ( \pm SE $0.9 \%$ ) on the 22 July (Figure $1 \mathrm{~b})$. Downy mildew developed significantly faster on B. napus and B. nigra plants from the 8 July onwards compared to other cruciferous species $\left(F_{5,12}=13.74, p<\right.$ $0.001)$. On $B$. juncea, downy mildew development progressed from the 15 July and culminated on the 22 July at $30 \%$ $( \pm$ SE $11.2 \%)$. Eruca sativa and $R$. sativus plants were infected only slightly by the end of observation period $(<1 \%)$. By the end of the observation period, $80 \%$ ( \pm SE $4.8 \%$ ) of foliage was infected by downy mildew on the B. napus plots (BBCH $72-74)$ and $64 \%( \pm$ SE $7.8 \%)$ on B. nigra plots (BBCH $75-77$ ) (Figure 1a).

In this study, we assessed the development of downy mildew on B. napus (the main crop) and compared it with the disease development in five alternative oilseed crops. In both growing seasons, the weather conditions were such that downy mildew assessments were possible, but the development of the disease was somewhat different. June 2010 was wet and cool, thus excellent for infection and spread of downy mildew. In 2010, the disease infection started a week earlier, but the infection pressure was lower, and downy mildew spread stopped also earlier compared to the growing season 2011. Overall, the growing season 2011 turned out more favourable for downy mildew development. However, conidia of $\mathrm{H}$. brassicae can germinate in temperatures ranging widely from 5 to $30^{\circ} \mathrm{C}$, and the optimum for germination is $15-25^{\circ} \mathrm{C}$ (Achar, 1998). Downy mildew pathogen conidia germinate when exposed to free water, and once germinated the most rapid development of downy mildew occurs at temperatures between $20-24^{\circ} \mathrm{C}$ (Larka, 2001).

Based on AUDPC values, downy mildew pressure differed significantly between the two observation years $\left(F_{1,24}=\right.$ $32.35, P<0.001)$ and test species $\left(F_{5,24}=50.25, P<0.001\right)$. Although the disease pressure in 2010 was lower, there were still significant differences in AUDPC values between six studied crops $\left(F_{5,12}=11.03, P<0.001\right)$. In 2010 , two crops, $E$ sativa and $R$. sativus, had no infection at all, and $S$. alba had a very low AUDPC value of 14.8 (Figure 2). In this year, the highest value of 344 was observed in B. nigra. Similarly, in 2011, significant differences between six test crops were found $\left(F_{5,12}=9.08, P<0.001\right)$. AUDPC values were very low in three crops: $<2.0$ in $E$. sativa and $R$. sativus and 8.9 on $S$. alba (Figure 2). The highest AUDPC values were 751 in B. napus and 608 in B. nigra plants (Figure 2). Combined two-year data showed a significant interaction effect of year and species on the AUDPC value for downy mildew $\left(F_{5,24}=19.67, P<0.001\right)$, indicating that B. napus and B. nigra were significantly more susceptible in 2011 than 2010.

Quantitative disease resistance assessment on downy mildew with AUDPC showed significantly lower infection values in the 2010 growing season than in 2011. Downy mildew caused diseases are polycyclic. Each step of the life cycle, including conidial germination, infection, latency and sporulation, is influenced by weather conditions (Kofoet \& Fink, 2007). In addition, significant differences in foliar resistance to downy mildew were found between six tested cruciferous crops. Eruca sativa (arugula) cultivar 'Poker' and $R$. sativus cultivar 'Bille' plants were not infected in 2010 , and even under the very favourable conditions in 2011, the infection started at the end of the observation period and stayed at a very low level. In contrast, in more humid conditions, e.g. in Korea Yongin region downy mildew poses a serious threat to arugula production in plastic greenhouses (Choi et al., 2010). On S. alba plants, the downy mildew infection rates in both growing seasons were also less than $2 \%$ and $B$. juncea was moderately infected. Similarly, in the study of Mohammed et al. (2018b), B. juncea cultivar 'Dune' showed the greatest resistance, particularly the older plants 
(40 day-old-plants). At the same time, two cruciferous species, B. nigra and B. napus were susceptible to downy mildew. Similarly, Van de Wouw et al. (2016) observed significantly less downy mildew on a $B$. juncea breeding line, compared to $B$. napus cultivars. Resistance to $H$. brassicae in diverse cruciferous host range offers new disease management approaches (Mohammed et al., 2019). Given that downy mildew poses a considerable threat to oilseed crops, resistant species and resistant cultivars available for several crops should be harnessed, especially in organic management.

On both growing seasons, the temperature was warmer than long-term average. Our results showed strong interaction between year and species to the downy mildew susceptibility. There are several reports of severe attacks of $H$. brassicae on cruciferous oilseed crops or vegetables (Mohammed et al., 2017; Coelho et al., 2002; Carlsson et al., 2004). Thus, in more favourable conditions pathogen $\mathrm{H}$. brassicae is able to cause even higher damage as in this study found in northern Baltics. Therefore more resistant crops and cultivars is necessary to seek out and cultivate.

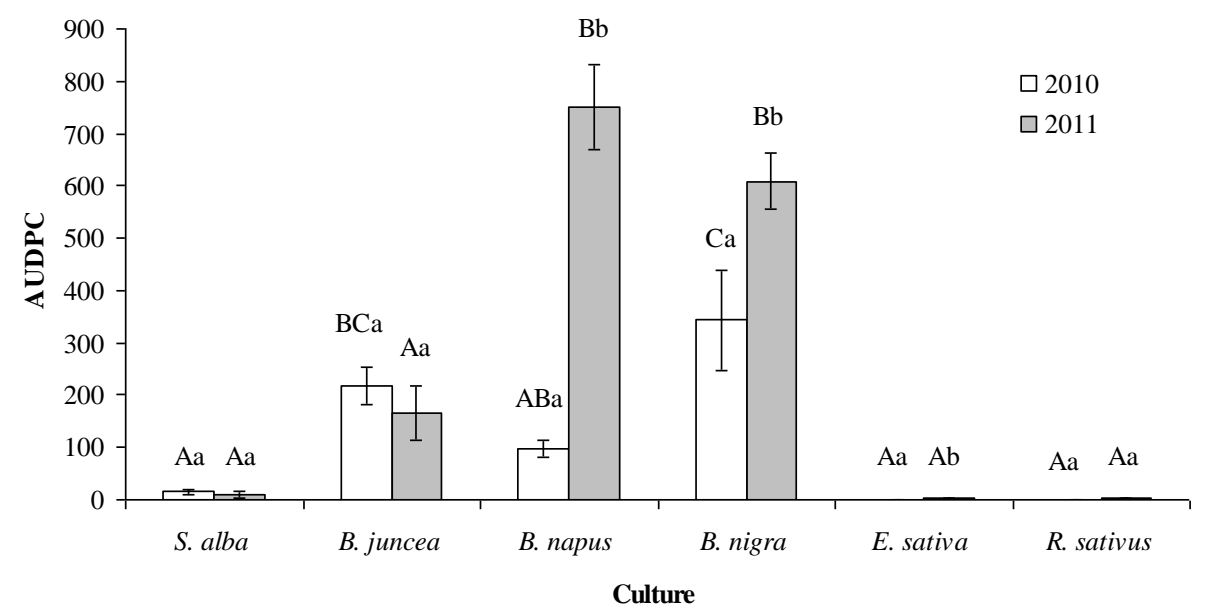

* Error bars denote the standard error of the means. Means followed by different capital letters above each bar indicate a significant influence $(P<0.05)$ of cruciferous oilseed crops in different years (Tukey HSD test). Means followed by different small letters above each bar indicate a significant influence $(P<0.05)$ of year (Tukey HSD test).

Figure 2. Mean area under the disease progress curve (AUDPC) values of downy mildew (H. brassicae) infection on different cruciferous oilseed crops.

\section{CONCLUSIONS}

These results provide useful suggestions in environmentally sustainable plant cultivation (green manure and cover crops) and plant protection (trap crops) strategies, which are based on multitrophic interactions. In both growing seasons downy mildew (H. brassicae) infection was registered on most test crop species. The two growing seasons were different, but the results clearly highlighted a consistent variability in the susceptibility to disease among studied species. Based on our field trial results, $S$. alba, E. sativa and $R$. sativus had significantly less downy mildew infection compared to other tested crops. Furthermore, in 2010 downy mildew on E. sativa and $R$. sativus was not recorded. Besides oilseed rape (B. napus), also black mustard (B. nigra) was susceptible to downy mildew. This must be considered especially in organic cultivation where synthetic fungicides are not allowed for disease control. The results of our study demonstrated that downy mildew is for spring oilseed rape and black mustard in Estonian field conditions a considerable, rather than minor disease. Given that wetter conditions are expected under global climate change in Estonia (Sepp et al., 2018; Climate Change Adaptation Development Plan until 2030), that can particularly favour polycyclic diseases, we argue that downy mildew can become an even more significant pathogen in Estonia in future climates. Thus, more attention should be paid to cultivar resistance of spring oilseed rape and other cruciferous oilseed crops and resistance to downy mildew should be included in local resistance breeding programmes.

Acknowledgements. The study was supported by the Estonian Science Foundation grant no 9432, Estonian Research Council (grant IUT 36 - 2), the European Regional Development Fund (project RESIST 3.2.0701.11-0003 and Center of Excellence EcolChange: Ecology of global change: natural and managed ecosystems) and the Estonian University of Life Sciences project (base funding P180273PKTT) and the Estonian University of Life Sciences project (base funding P190259PKTT).

\section{REFERENCES}

1. Achar P.N. 1998. Effects of temperature on germination of Peronospora parasitica conidia and infection of Brassica oleracea. Journal of Phytopathology 146, pp. 137-141. https://doi.org/10.1111/j.1439-0434.1998.tb04670.x

2. Bankina B., Gaile Z., Balodis,O., Paura L., Kokina I. 2012. Possibilities for integrated control of winter oilseed rape diseases in Latvia. EPPO Bulletin, Vol. 42 (3), pp. 560-567. https://doi.org/10.1111/epp.2601

3. Brandes M, Heimbach U. 2018. Pyrethroid resistance of insect pests of oilseed rape in Germany. Integrated Control in Oilseed Crops. IOBC-WPRS Bulletin, Vol. 136, pp. 69-72. 
4. Carlsson M., von Bothmer R., Merker A. 2004. Screening and evaluation of resistance to downy mildew (Peronospora parasitica) and clubroot (Plasmodiophora brassicae) in genetic resources of Brassica oleracea. Hereditas, Vol. 141, pp. $293-300$. https://doi.org/10.1111/j.1601-5223.2004.01818.x

5. Choi Y.J., Park M.J., Kim J.Y., Shin H.D. 2010. An unnamed Hyaloperonospora sp. causing downy mildew on arugula (rocket) in Korea. Plant Pathology, Vol. 59, pp. 1165. https://doi.org/10.1111/j.1365-3059.2010.02290.x

6. Climate Change Adaptation Development Plan until 2030. Future climate in Estonia. Republic of Estonia Ministry of the Environment, pp 6-9. Available at https://www.envir.ee/sites/default/files/national_adaptation_strategy.pdf (accessed on 06/09/2019)

7. Coelho P.S., Monteiro A.A. 2018. Genetic and histological characterization of downy mildew resistance at the cotyledon stage in Raphanus sativus L. Euphytica, 214, 208. Available at https://doi.org/10.1007/s10681-018-2289-x (accessed on 22/08/2019) https://doi.org/10.1007/s10681-018-2289-X

8. Coelho P.S., Vicente J.G., Monteiro A.A., Holub E.B. 2012. Pathotype diversity of Hyaloperonospora brassicae collected from Brassica oleracea. European Journal of Plant Pathology, Vol. 134, pp. 763-771. https://doi.org/10.1007/s10658-012-0052-Z

9. Coelho, P.S., Monterio, A.A. 2003. Inheritance of downy mildew resistance in mature broccoli plants. Euphytica 131, pp. 65-69. https://doi.org/10.1023/A:1023008619400

10. EPPO Bulletin. 2003. Efficacy evaluation of fungicides: Root, stem, foliar and pod diseases of rape. EPPO Bulletin, Vol. 33, pp. 25-32. https://doi.org/10.1046/j.1365-2338.2003.00615.x

11. George A.T. 2014. Brassicas: cabbage and related crops. Diseases of temperate horticultural plants. Edited by R.A.T George and R.T.V. Fox, CAB International, pp. 174-176.

12. Hardwick N.V., Fitt B.D.L., Wale S.J., Sweet J.B. 1991. Oilseed rape diseases. Home-Grown Cereals Authority Review Articles, Home-Grown Cereals Authority, London

13. Ilumäe E., Kastanje V., Hansson A. 2009. Valgemädaniku (Sclerotinia sclerotiorum (Lib.) DeBary) mõju suvirapsi (Brassica napus) saagikusele I-Taimekaitse katsetes 2007-2008. The impact of Sclerotinia stem rot (Sclerotinia sclerotiorum (Lib.) De Bary) on the yielding of spring rape (Brassica napus). In Estonian. Agronoomia, 1 k. pp. 198-203.

14. Järvan M. 2016. Kas nuutrihaigus võib rapsikasvatust ohustada? Põllumajanduslikud infopäevad 2016, Oilseeds, 1k. 4-5.

15. Kiiker R, Hansen M, Williams IH, Cooke DEL, Runno-Paurson E. 2018. Outcome of sexual reproduction in the Phytophthora infestans population in Estonian potato fields. Eur. J. Plant Pathol. 152:395-407. https://doi.org/10.1007/s10658-018-1483-y

16. Kiiker R., Skrabule I., Ronis A., Cooke D.E.L., Hansen J.G., Williams I.H., Mänd M., Runno-Paurson E. 2019. Diversity of populations of Phytophthora infestans in relation to patterns of potato crop management in Latvia and Lithuania. Plant Pathology, Vol. 68(6), pp. 1207-1214. https://doi.org/10.1111/ppa.13030

17. Kofoet A., Fink M. 2007. Development of Peronospora parasitica epidemics on radish as modelled by the effects of water vapour saturation deficit and temperature. European Journal of Plant Pathology, Vol. 117, pp. 369-381. https://doi.org/10.1007/s10658007-9106-Z

18. Kovacs G., Kaasik R., Kortspärn K., Metspalu L., Luik A., Veromann E. 2015. Naeri-hiilamardika resistentsusprobleem Eestis näitab süvenemise märke. Alaru, M., Astover, A., Karp, K., Viiralt, R.. Must, A. (Toim.). Agronoomia, pp. 138-141.

19. Kovacs G., Kaasik R., Kaart T., Metspalu L., Luik A., Veromann E. 2017. In search of secondary plants to enhance the efficiency of cabbage seed weevil management. BioControl, Vol. 62, pp. 29-38. https://doi.org/10.1007/s10526-016-9765-9

20. Lancashire P.D., Bleiholder H., Boom T.V.D., Langelüddeke P., Strauss R., Weber E., Witzenberger A. 1991. A uniform decimal code for growth stages of crops and weeds. Annals of Applied Biology, Vol. 119, pp. 561-601. https://doi.org/10.1111/j.17447348.1991.tb04895.x

21. Larka B.S. 2001. Epiphytology and losses of downy mildew (Peronospora parasitica) of radish (Raphanus sativus) seed crop. Indian Journal of Agricultural Sciences, Vol. 71, pp. 321-324.

22. Larkin R.P., Griffin T.S., Honeycutt C.W. 2010. Rotation and cover crop effects on soilborne potato diseases, tuber yield, and soil microbial communities. Plant Disease, Vol. 94(12), pp. 1491-1502. https://doi.org/10.1094/PDIS-03-10-0172

23. Larkin, R.P., Halloran, J.M. 2014. Management effects of disease-suppressive rotation crops on potato yield and soilborne disease and their economic implications in potato production. American Journal of Potato Research, Vol. 91, pp. 429-439. https://doi.org/10.1007/s12230-014-9366-Z

24. Larkin, R.P. 2017. Incorporating disease-suppressive rotation crops and organic amendments into improved potato cropping systems. Phytopathology, Vol. 107, pp. 48-48.

25. Mayton H., Smart C. D., Moravec B. C., Mizubuti E. S. G., Muldoon A. E., Fry W. E. 2000. Oospore survival and pathogenicity of single oospore recombinant progeny from 23 a cross involving US-17 and US-8 genotypes of Phytophthora infestans. Plant Disease, Vol. 84, pp. 1190-1196. https://doi.org/10.1094/PDIS.2000.84.11.1190

26. Metspalu L., Kruus E., Ploomi A., Williams I.H., Hiiesaar K., Jõgar K., Veromann E., Marika M. 2014. Flea beetle (Chrysomelidae: Alticinae) species composition and abundance in different cruciferous oilseed crops and the potential for a trap crop system. Acta Agriculturae Scandinavica, Section B-Soil \& Plant Science, Vol. 64 (7), pp. 572-582. https://doi.org/10.1080/09064710.2014.933871

27. Metspalu L., Veromann E., Kaasik R., Kovacs G., Williams I.H., Mänd M. 2015. Comparison of sampling methods for estimating the abundance of Meligethes aeneus on oilseed crops. International Journal of Pest Management, Vol. 61 (4), pp. 312-319. https://doi.org/10.1080/09670874.2015.1058992

28. Mohammed A.E., You M.P., Barbetti M.J. 2017. New resistances offer opportunity for effective management of the downy mildew (Hyaloperonospora parasitica) threat to canola. Crop \& Pasture Science, Vol. 68, pp. $234-242$. https://doi.org/10.1071/CP16363 
29. Mohammed A.E., You,M.P., Al-lami F.D., Barbetti M.J. 2018a. Pathotypes and phylogenetic variation determine downy mildew epidemics in Brassica spp. in Australia. Plant Pathology, Vol. 67, pp. 1514-1527. https://doi.org/10.1111/ppa.12861

30. Mohammed A.E., You Barbetti M.J. 2018b. Temperature and plant age drive downy mildew disease epidemics on oilseed Brassica napus and B. juncea. European Journal of Plant Pathology, Vol. 151 (3), pp. 703-711. https://doi.org/10.1007/s10658$\underline{017-1404-5}$

31. Mohammed A.E., You M.P., Banga S.S., Barbetti M.J. 2019. Resistances to downy mildew (Hyaloperonospora brassicae) in diverse Brassicaceae offer new disease management opportunities for oilseed and vegetable crucifer industries. European Journal of Plant Pathology, Vol. 153, pp. 915-929. https://doi.org/10.1007/s10658-018-01609-7

32. Olanya O.M., Larkin R.P., Halloran J.M. 2014. Relationships of crop and soil management systems to meteorological variables and potato diseases on a Russet Burbank cultivar. Journal of Agricultural Meteorology, Vol. 70, pp. 91-104. https://doi.org/10.2480/agrmet.D-13-00022

33. Oxley S., Evans A. 2009. Winter oilseed rape pests and diseases. Technical Note TN620, June 2009. The Scottish Agricultural College.

34. Petraitiene E. 2006. Major fungal diseases of oilseed rape (Brassica napus) in Lithuania. International Consultative Group for Research on Rapeseed. Bulletin, No 23, pp. 1-6.

35. Runno-Paurson E., Hansen M., Tein B., Loit K., Luik A., Metspalu L., Eremeev V., Williams I.H., Mänd M. 2014. Cultivation technology influences the occurrence of potato early blight in an organic farming system. Zemdirbyste-Agriculture, Vol. 101(2), pp. 199-204. https://doi.org/10.13080/z-a.2014.101.026

36. Runno-Paurson E., Loit K., Hansen M., Tein B., Williams I.H., Mänd M. 2015. Early blight destroys potato foliage in the northern Baltic region. Acta Agriculturae Scandinavica Section B - Soil \& Plant Science, Vol. 65(5), pp. 422-432. https://doi.org/10.1080/09064710.2015.1017003

37. Runno-Paurson E., Lääniste P., Eremeev V., Tähtjärv T., Kaurilind E., Tosens T., Niinemets Ü., Williams I.H. 2019. Does winter oilseed rape as a winter cover crop influence potato late blight development in an organic crop rotation? Biological Agriculture \& Horticulture. https://doi.org/10.1080/01448765.2019.1680432

38. Saharam G.S., Mehta N., Meena, P.D. 2018. Downy mildew disease of crucifers: biology, ecology and disease management. Springer Nature Singapore Pte Ltd. 2017, 357 p. https://doi.org/10.1007/978-981-10-7500-1

39. Sepp M., Tamm T., Sagris V. 2018. The future climate regions in Estonia. Estonian Journal of Earth Sciences 67(4), pp. 259-268. https://doi.org/10.3176/earth.2018.19

40. Shaner G., Finney RE. 1977. The effect of nitrogen fertilization on the expression of slow-mildewing resistance in Knox wheat. Phytopathology, Vol. 67, pp. 1051-1056. https://doi.org/10.1094/Phyto-67-1051

41. Statistics Estonia, 2019. Sown area of field crops, data base. Available at. http://andmebaas.stat.ee/Index.aspx?lang=en\&SubSessionId=98b16850-36fb-4113-8f45-1bc7fa42b930\&themetreeid=3 (accessed on 05/04/2019)

42. Van de Wouw A.P., Idnurm A., Davidson J.A., Sprague S.J., Khangura R. K., Ware A.H., Lindbeck K.D., Marcroft S.J. 2016. Fungal diseases of canola in Australia: identification of trends, threats and potential therapies. Australasian Plant Pathology, Vol. 45, pp. 415-423. https://doi.org/10.1007/s13313-016-0428-1

43. Veromann E., Metspalu L., Williams I.H., Hiiesaar K., Mänd M., Kaasik R., Kovacs G., Jõgar K., Svilponis E., Kivimägi I. 2012. Relative attractiveness of Brassica napus, Brassica nigra, Eruca sativa and Raphanus sativus for pollen beetle (Meligethes aeneus) and their potential for use in trap cropping. Arthropod-Plant Interactions, Vol. 6, pp. $385-394$. https://doi.org/10.1007/s11829-012-9191-6

44. Yuen J. E., Andersson B. 2013. What is the evidence for sexual reproduction of Phytophthora infestans in Europe? Plant Pathology, Vol. 62, pp. 485-491. https://doi.org/10.1111/j.1365-3059.2012.02685.x 